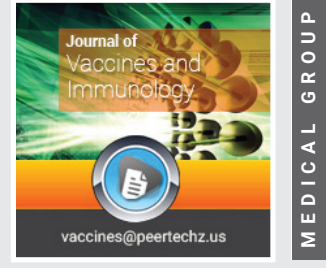

Letter to Editor

\section{COVID-19, nursing publication and the future of nursing}

\section{research infection}

\author{
Salam Banihani* \\ Clinical Instructor, Department of Adult Health Nursing, Faculty of Nursing, Al Albayt University, \\ Mafraq, Jordan
}

Received: 19 July, 2021

Accepted: 23 July, 2021

Published: 24 July, 2021

*Corresponding author: Salam Banihani, RN, MSN, PhD Student, Clinical Instructor, Department of Adult Health Nursing, Faculty of Nursing, Al Albayt University, Mafraq, Jordan, Tel: 0785577701; E-mail: banihani. salam@yahoo.com, sbanihani@aabu.edu.jo ORCID: https://orcid.org/0000-0003-0848-5615 https://www.peertechzpublications.com

\section{Check for updates}

Despite the advance in health sciences, the more frequent emerging of infectious diseases in recent decades raise due to environmental changes such as human activity, poor health care system, microbial adaptation, and substantial international movement [1]. This virus has a high mutation ratio with a substantial spread among the population through droplets, airborne, and contact as modes of transmission [2]. Generally, the Coronavirus affected our way of life and specifically the way of carrying out the research. It has significantly affected clinical research trials. Translational research that has the main role in moving the scientific findings into practice health care provision [3] must take place in improving the collaboration between research centers and hospitals where patients were recruited and finding ways to bridge the gap in funding projects. During the outbreak, many innovative technologies emerged such as virtual meetings in the health care systems and telehealth including telenursing technology which is considered as a cornerstone of health care in recent decades [4]. It is crucial to take the benefits of this technology in the research field, and cooperate at the national and international level to advance research in all aspects including efficacy, recruitment of participants, results, and dissemination of findings [5].

Since the time of the pandemic outbreak, a lot of reports have been published or submitted as preprint platforms. Globally, the researchers spent great efforts depending on the field and the available resources to carry out their scientific work in different disciplines including immunology [2], disease transmission, infection control practices, experimental treatment, and vaccine development. A substantial increase in scientific creation has been documented in several databases about COVID-19 [6]. However, scientists and researchers should collaborate to mobilize shared resources and strengthen the role of evidence-based practices to address the COVID-19 pandemic around the world. Developing future nursing infection research is important if the focus to enhance nursing eventually enhances health care generally.

Many aspects of COVID-19 confront health care providers with exclusive risks and challenges including a nursing shortage workforce in low and middle-income countries that will put nurses in high job demand and increased risk of infection, physical distress, and emotional strain [7]. The virus is highly contagious which pushes them to fear contracting the virus for themselves and their families. Another point is the restriction of visitors which enforce nurses to provide emotional support and comfort since they were the only available health care providers to introduce care to their patients. These risks put nurses in an ethical dilemma when they are trying to fulfill professional ethical obligations and their personal beliefs and priorities [8]. Nursing ethics research can address this type of restraining since it suggests establishing a healthy ethical climate and supportive institutional policy that can deal with several ethical issues, concerns, and stress. COVID-19 put the nurses forward for many opportunities by implementing humanistic theory in their practice that let them work with their patient's with the human spirit and ethical commitment regardless of the threat of getting an infection, contingency management, creativity, leading infection, and control measures in practice, and selfesteem through sharing patient's stories since they cannot see their families [7].

Sharing the information and being open to the data in 
regards to the virus is an important step since it allows to compare and validate the information in a different context. A vast amount of submitted manuscripts to peer-reviewed journals around the world during the period of COVID-19 play a key role in this process. But, we need to create a system to filter and evaluate the huge amount of scientific information, since the quality of manuscripts and published data is quite variable. The health care system faces many challenges with the expanding body of science and increases the number of published articles [9]. This challenge was inflamed due to the gap between theory and practice. And many researchers were just publishing their articles for personal purposes to increase their number of citations, articles, publications as well as $\mathrm{H}$-index to be prominent researchers in the community. However, no efforts were spent to improve community health and awareness of the public regarding the emerging and reemerging of infectious diseases [3].

Researchers in the field of public health, big data, applied and medical fields from universities, governmental agencies, and private sectors should utilize significant contributions and innovation on COVID-19. Also, in the era of the current pandemic, there is a great need to continue research activities while keeping both participants and researchers safe. Supporting research activities using remote conducting research methodologies such as telehealth, to save time and cost, improve easy access of participants to being part of studies, improve the generalizability of findings, enrich publication of study finding that impact translational research positively, and keep the participants and researchers from the potential risk of viral transmission [10]. Also, it should take the benefits from bibliometric analysis to guide researchers and scientists in conveying institutional protocols to conduct COVID-19 research to accomplish great visibility and impact [11].

\section{References}

1. Ellwanger JH, Kaminski VL, Chies JAB (2019) Emerging infectious disease prevention: Where should we invest our resources and efforts? J Infect Public Health 12: 313-316. Link: https://bit.ly/3kJUrH7

2. Priyanka, Choudhary OP, Singh I, Patra G (2020) Aerosol transmission of SARS-CoV-2: The unresolved paradox. Travel Med Infect Dis 37: 101869. Link: https://bit.ly/3fuxQtT

3. Jalali R, Hosseinian-Far A, Mohammadi M (2021) Contradictions in the promotion of publishing academic and scientific journal articles, and the inability to cope with the new coronavirus (COVID-19). Antimicrobial Resistance \& Infection Control 10: 1-3. Link: https://bit.ly/3zprFQ0

4. Nicole B, Francesco C (2017) Telenursing: Bioinformation cornerstone in healthcare for the $21^{\text {st }}$ century. Bioinformation 13: 412. Link: https://bit.ly/3eMSDt3

5. Magan AA, Plastow R, Haddad FS (2020) Impact of COVID-19 on research Bone Joint Res 9: 531-533. Link: https://bit.ly/3hV6L5s

6. El Mohadab M, Bouikhalene B, Safi S (2020) Bibliometric method for mapping the state of the art of scientific production in Covid-19. Chaos, Solitons \& Fractals 139: 110052. Link: https://bit.ly/3kOBjre

7. Pachya AT, Pachya U, Thapa N, Tandukar R, Singh J, et al. (2020) Challenges and opportunities for nurses during COVID-19 pandemic.

8. Eileen LT (2020) How effective response to COVID-19 relies on nursing research. Res Nurs Health 43: 213-214. Link: https://bit.ly/3rusm7M

9. Martin B, Phoenix BJ, Chapman SA (2020) How collaborative practice agreements impede the provision of vital behavioral health services. Nurs outlook 68: 581-590. Link: https://bit.ly/2TtcZQw

10. Saberi $P$ (2020) Research in the time of coronavirus: continuing ongoing studies in the midst of the COVID-19 pandemic. AIDS Behav24: 2232-2235. Link: https://bit.ly/3zsWOND

11. López-López W, Salas G, Vega-Arce M, Cornejo-Araya CA, BarbozaPalomino M, et al. (2020) Publications on COVID-19 in High Impact Factor Journals: A Bibliometric Analysis. Universitas Psychologica 19: 1-12. Link: https://bit.ly/3xaf2ad

\section{Discover a bigger Impact and Visibility of your article publication with}

\section{Peertechz Publications}

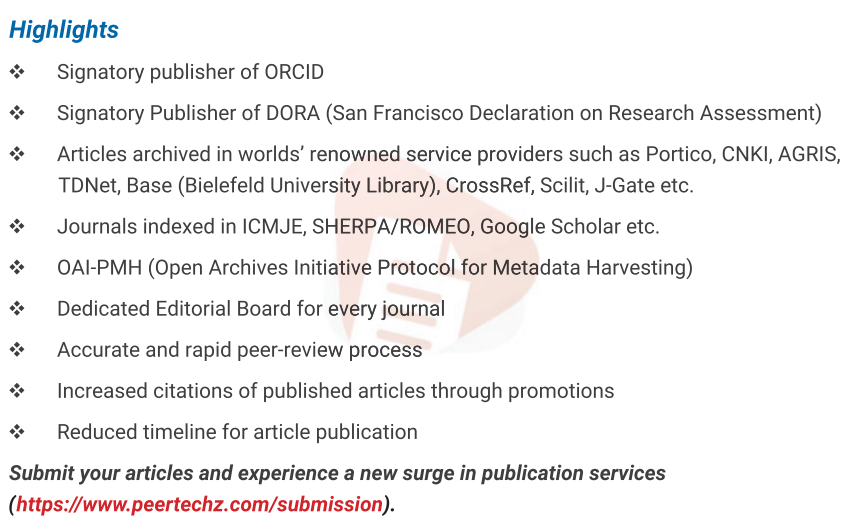

Peertechz journals wishes everlasting success in your every endeavours.

Copyright: @ 2021 Banihani S. This is an open-access article distributed under the terms of the Creative Commons Attribution License, which permits unrestricted use distribution, and reproduction in any medium, provided the original author and source are credited. 